\begin{tabular}{|c} 
Ambiente \& Água - An Interdisciplinary Journal of Applied Science \\
ISSN 1980-993X - doi:10.4136/1980-993X \\
www.ambi-agua.net \\
E-mail: ambi.agua@gmail.com
\end{tabular}

\title{
Analysis and modeling of water quality as a contribution to the preliminary framework proposal for the Una River (Pernambuco/Brazil)
}

\author{
ARTICLES doi:10.4136/ambi-agua.2251 \\ Received: 09 Mar. 2018; Accepted: 12 Oct. 2018
Simone Rosa da Silva1; Marcos Antonio Barbosa da Silva Junior ${ }^{2 *}$; Eduardo Elvino Sales de Lima ${ }^{3}$ \\ ${ }^{1}$ Universidade de Pernambuco (UPE), Recife, PE, Brasil \\ Departamento de Engenharia Civil. E-mail: simonerosa@poli.br \\ ${ }^{2}$ Universidade Federal de Pernambuco (UFPE), Recife, PE, Brasil \\ Departamento de Engenharia Civil. E-mail: marcos15barbosa@ hotmail.com \\ ${ }^{3}$ Agência Estadual de Meio Ambiente (CPRH), Recife, PE, Brasil \\ E-mail: eduardoelvino@hotmail.com \\ *Corresponding author
}

\begin{abstract}
The present paper presents a preliminary proposal for a framework for the Una River, located in the state of Pernambuco, divided into prevailing-use classes. This proposal integrates the results of an analysis of water quality parameters and a mathematical modeling performed along a section of the river. Data from six State Environmental Agency (CPRH) monitoring stations were used, which collected data for temperature, $\mathrm{pH}, \mathrm{DO}, \mathrm{BOD}$, phosphorus, thermotolerant coliforms, turbidity, and color between 2002 and 2014. The mathematical model used was QUAL-UFMG and the parameters evaluated were DO and BOD. The results showed that the DO and BOD parameters were within the limits established by CONAMA Resolution No. 357/2005 for Class 2, but other parameters such as phosphorus presented nonconformities. Based on this, the proposed framework for the Una River covered Classes 1 and 2. It is hoped that such a proposal will serve as a reference for the basin committee in order to discuss and deliberate on the multiple uses preponderant along the river, aiming to approve and implement the framework.
\end{abstract}

Keywords: framework, Una river, water quality.

\section{Análise e modelagem da qualidade da água como subsídio à proposta preliminar de enquadramento do rio Una (Pernambuco/Brasil)}

\section{RESUMO}

O presente trabalho apresenta uma proposta preliminar para o enquadramento do rio Una, localizado no estado de Pernambuco, em classes de usos preponderantes. Esta proposta integra os resultados da análise dos parâmetros da qualidade da água e da modelagem matemática realizada num trecho do rio. Foram utilizados os dados do monitoramento de seis estações da Agência Estadual de Meio Ambiente - CPRH, entre os anos de 2002 e 2014, e analisados os parâmetros de temperatura, $\mathrm{pH}, \mathrm{OD}, \mathrm{DBO}$, fósforo, coliforme termotolerantes, turbidez e cor. 
Na modelagem matemática, o modelo utilizado foi o QUAL-UFMG e os parâmetros avaliados foram o OD e DBO. Os resultados mostraram que os parâmetros de OD e DBO ficaram dentro dos limites estabelecidos pela Resolução CONAMA n ${ }^{\circ}$ 357/2005 para a Classe 2, porém outros parâmetros como o fósforo apresentaram desconformidades em seus índices. Com base nisso, o enquadramento preliminar proposto para o rio Una abrangeu as Classes 1 e 2. Espera-se que tal proposta sirva como referência ao comitê da bacia, para que sejam discutidos e deliberados os usos múltiplos preponderantes ao longo do rio, objetivando assim, a aprovação e implementação do enquadramento.

Palavras-chave: enquadramento, qualidade da água, rio Una.

\section{INTRODUCTION}

The term "framework" refers to the definition of quality goals to be achieved for water bodies within a river basin. In Brazil, the National Water Resources Policy (Federal Law no 9.433/1997) establishes that the framework for water bodies divided into prevailing use classes, as defined by CONAMA Resolution $n^{\circ} 357 / 2005$, should guarantee the necessary water quality standards for the most restrictive uses. In basins where the current condition of the water body quality is not appropriate for its intended uses, targets should be established to implement the respective frameworks, as recommended by CNRH Resolution $n^{\circ}$ 091/2008 (Brasil, 1997; CONAMA, 2005; CNRH, 2008).

In order to simulate water quality parameters in compliance with the proposed framework, simplified one-dimensional mathematical models are commonly used, which represent flow through the average velocity in the cross section, neglecting the vertical and transverse variations. With the advancement of computing, it is possible to perform spatially distributed modeling using geographic information systems (GIS), allowing the integration between point and diffuse pollution sources. These models can also be integrated into decision support systems for water-resource management in a watershed (Fan et al., 2012; Gomes and Simões, 2014; Silva et al., 2017).

The Una River basin does not have a framework prevailing use class. In the absence of this instrument, current legislation (CONAMA n ${ }^{\circ} 357 / 2005$ ) establishes that fresh water bodies are to be considered Class 2. According to the Pernambuco State Water Resources Policy (State Law $\mathrm{n}^{\circ}$ 12.984/2005, Article 55, XI and Article 47, VI), the proposed framework should be made by the Basin Agency, approved by the Basin Committee and later ratified by the State Council of Water Resources. In the absence of the Basin Agency, the above-mentioned State Law (Article 48, XIII) assigns responsibility for the elaboration of said proposal to the management and environmental body (Pernambuco, 2005).

With the goal of contributing as a theoretical subsidy for future framework proposals in the Una River basin, the present article presents a preliminary study for the classification of the main river into a prevailing-use class, based on the analysis of water quality parameters, mathematical modeling, and current water use.

\section{MATERIALS AND METHODS}

\subsection{Characterization of the study area}

The study area is the Una River basin that covers parts of the states of Pernambuco and Alagoas. With a total area of $6,740.31 \mathrm{~km}^{2}$, of which $6,262.78 \mathrm{~km}^{2}$ are in Pernambuco, the basin in question covers totally or partially 42 municipalities. The principal river, of the same name as the basin, has a length of $290 \mathrm{~km}$ with its source located in the municipality of Capoeiras, having intermittent flow until approximately the town of Altinho, where it becomes perennial (Figure 1). 


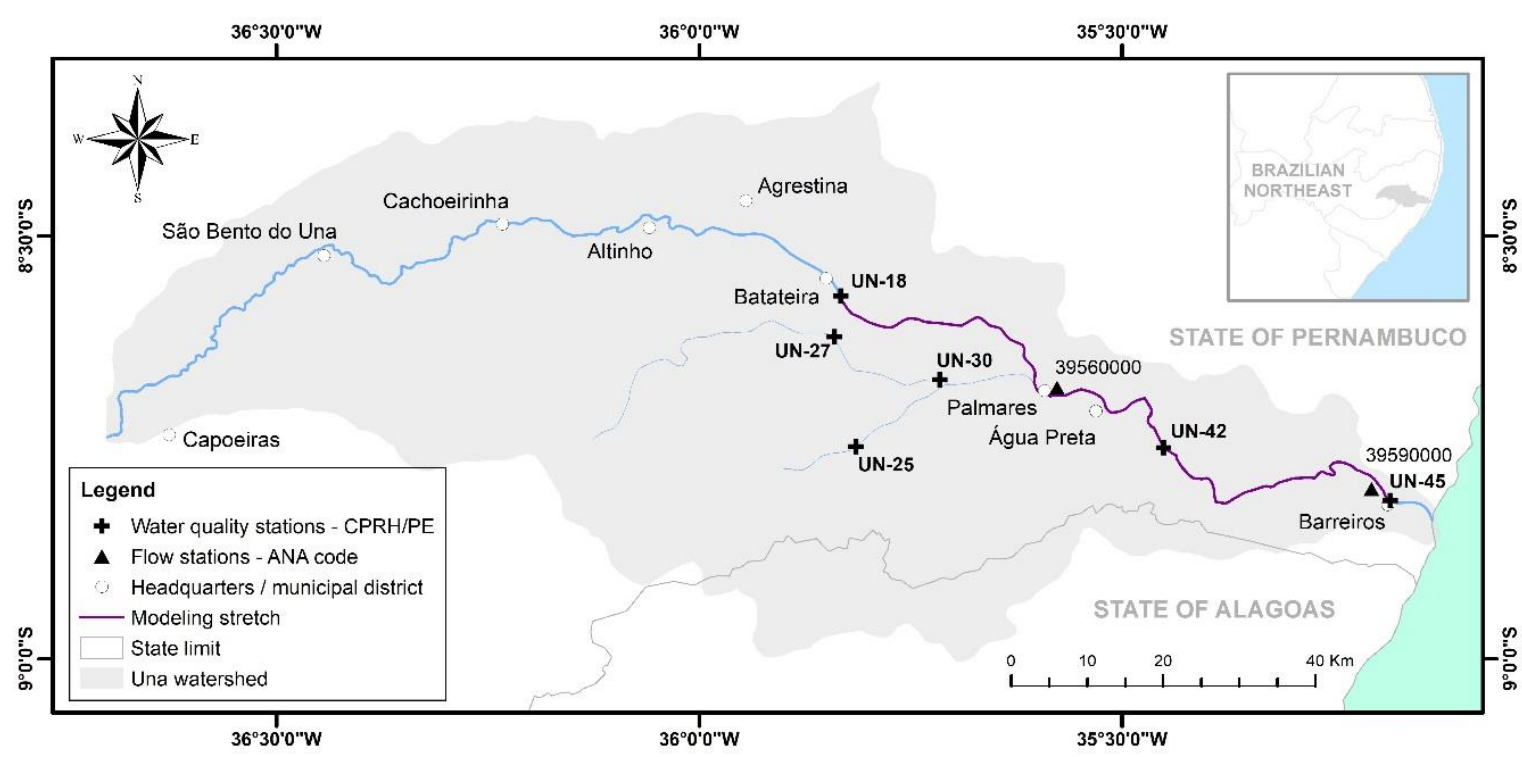

Figure 1. Map showing the location of the Una River hydrographic basin.

The most significant uses for the water in the basin are focused on public water supply and irrigation of short- and long-cycle crops. Due to the use and occupation of the soil (which houses urban areas, public slaughterhouses, industries, polyculture and sugar cane cultivation), the Una River became a receptacle for domestic, agroindustrial, and industrial effluents (the main source of pollution). According to Lima (2016), the release of industrial effluents decreased significantly with the deactivation of several sugar and alcohol sector plants in the basin. Only the Pumaty Plant, located in the municipality of Palmares, remains in operation. Despite this, sugarcane plantations continue across large parts of the basin, provoking an increase in nutrient concentration in the Una River, due to fertirrigation practices.

In this current situation, the water quality of the Una River is moderately compromised. The results of the monitoring carried out in December 2017 by the State Environmental Agency (CPRH) indicate that the river has regular water quality conditions (with acceptable levels of pollution) and is compatible with the limits of Class 3 (CPRH, 2018).

The Una River Basin Committee (COBH Una, in Portuguese) was created by CRH/PE Resolution $\mathrm{n}^{\mathrm{o}}$ 005/2002. It has 24 members for the 2015-2018 term, these being 12 representatives of the municipal, state, and federal governments, 8 representatives of water users in the basin, and 4 representatives of civil entities. Currently, the Una River basin has no master water plan nor any framework, as already mentioned. In general, the focus of the attention of $\mathrm{COBH}$ Una is controlling flooding, which has caused significant damages in several municipalities in the basin during 2010 and 2017.

\subsection{Water quality monitoring data}

Initially, data from all the monitoring stations operating in the basin were analyzed. The data were made available by the CPRH through its official website. The physicochemical and bacteriological analyses were carried out for six monitoring stations (three stations on the main river channel and three on its tributaries) between 2002 and 2010, with a bimonthly collection frequency for temperature, $\mathrm{pH}, \mathrm{DO}, \mathrm{BOD}$, color, turbidity, and phosphorus parameters and every four months for thermotolerant coliforms. After defining the parameters, the data were separated by year, station, and collection frequency, and further divided into dry (September to March) and rainy (April to August) seasons. In order to evaluate the empirical distribution of the data, boxplot charts were drawn in Excel to show the minimum, maximum, and median values. These results were then compared against the limits of the Class 2 standards. 


\subsection{Modeling the QUAL-UFMG water quality model}

The QUAL-UFMG model, developed by Von Sperling (2007) as an adaptation of the QUAL2E model, has been widely used by many Brazilian researchers to evaluate water quality, simulate scenarios, and predict water body behavior. It is a one-dimensional model, developed in a Microsoft Office Excel spreadsheet, suitable for rivers with relatively low permanent flows. It allows the modeling of river water quality through a simple and fast simulation of dissolved oxygen, biochemical oxygen demand, total nitrogen and its concentration, and coliform bacteria (Louzada Valory et al., 2016).

The choice of the above-mentioned model was based on the following criteria: ease of use, considering both the interface and the language; the utilization of basic parameters to qualitatively evaluate water resources ( $\mathrm{DO}, \mathrm{BOD}$, phosphorus, thermotolerant coliforms, temperature, $\mathrm{pH}$, color, and turbidity); availability of water quality monitoring data over a 10year period; and data on the flow of the water body to be modeled. In addition, this model had been previously used with other basins in Pernambuco, producing satisfactory results (Pinheiro et al., 2013; Araújo, 2013; Silva, 2015; Lima, 2016).

Although up to 15 organic components of water quality were simulated, two basic parameters were used to perform this study: dissolved oxygen (DO) and biochemical oxygen demand (BOD). To model DO and BOD in watercourses, Equation 1 is used to calculate the weighted average of the concentrations with the aggregated element flows. It is observed that the value of $\mathrm{C}_{0}$ is obtained through a weighted average of the flows, DO and BOD.

$$
C_{0}=\frac{Q_{r} \times C_{r}+Q_{r} \times C_{e}}{Q_{r}+Q_{e}}
$$

Where: $\mathrm{C}_{0}\left(\mathrm{DO}\right.$ or $\left.\mathrm{BOD}_{5}\right)$ : concentration of the mixture $\left(\mathrm{mg} \mathrm{L}^{-1}\right) ; \mathrm{C}_{\mathrm{r}}\left(\mathrm{DO}_{\mathrm{r}}\right.$ or $\left.\mathrm{BOD}_{\mathrm{r}}\right)$ : concentration in the river upstream from the mixing point $\left(\mathrm{mg} \mathrm{L}^{-1}\right) ; \mathrm{C}_{\mathrm{e}}\left(\mathrm{DO}_{\mathrm{e}}\right.$ or $\left.\mathrm{BOD}_{\mathrm{e}}\right)$ : concentration in the sewer upstream from the mixing point $\left(\mathrm{mg} \mathrm{L}^{-1}\right)$; and $\mathrm{Q}_{\mathrm{r}}$ and $\mathrm{Q}_{\mathrm{e}}$ : flows of the river and of the sewer $\left(\mathrm{m}^{3} \mathrm{~s}^{-1}\right)$.

The section to be modeled was defined based on the size of the series of historical flow and water quality data (DO and BOD) available at stations along the Una River. With this criterion, the data series from two ANA fluviometric stations (Palmares - code 39560000 and Barreiros - code 39590000) and three CPRH water quality stations (UN-18, UN-42, and UN45) were considered satisfactory, resulting in a modeled stretch $118 \mathrm{~km}$ long (Figure 1).

It is important to note that other relevant points were considered during the modeling, such as the inclusion of pollution sources from the sugar and alcohol sector (represented by the Pumaty Plant, the only one currently in operation) and the organic load resulting from the sewage of the municipalities of Palmares, Água Preta and Barreiros, as well as from their respective public slaughterhouses. The input data required and used by the QUAL-UFMG water quality mathematical model are presented below in a simplified manner:

- River flow $(Q r)$ and sewage flow (Qe): flow data were obtained from the Hydrological Information System (Hidroweb) of the National Water Agency (ANA) and stored with the software application Hidro 1.2, also made available by ANA. The sewage flow was estimated for the three municipalities mentioned above through the application of Equation 2, considering the 2010 population data (from IBGE), the per capita consumption of $250 \mathrm{~L} \mathrm{hab}^{-1} \mathrm{~d}^{-1}$, and using $80 \%$ as the coefficient of return. In addition, effluent outflows from public slaughterhouses were estimated for the high slaughter season, between October and December, based on the amount of cattle, pigs, and goats slaughtered per day. 
$Q_{e}=\left[\frac{\left(Q_{P C} \times P o p \times R\right)}{1000}\right] \div 8640$

Where: Qe: average domestic sewage flow $\left(\mathrm{m}^{3} \mathrm{~s}^{-1}\right)$; QPC: per capita water quota $\left(\mathrm{L} \mathrm{hab}^{-1} \mathrm{~d}^{-1}\right)$; Pop: population (hab); and R: coefficient of return.

- Dissolved oxygen in the river $\left(D O_{r}\right), B O D_{5,20}$ in the river $\left(B O D_{r}\right)$ and water temperature $(T)$ : these parameters were obtained from the average data of the six water quality monitoring stations between 2002 and 2010, for the dry period only.

- Dissolved oxygen in the sewage $\left(D O_{e}\right)$ and $B O D_{5,20}$ in the sewage $\left(B O D_{e}\right)$ : as most sewage from the municipalities as well as from public slaughterhouses is not treated, for the self-purification calculations, the $\mathrm{DO}_{\mathrm{e}}$ was considered to be $0 \mathrm{mg} \mathrm{L}^{-1}$. The $\mathrm{BOD}_{\mathrm{e}}$ was estimated by the division between the of $\mathrm{BOD}_{5}$ load $\left(\mathrm{kg} \mathrm{d}^{-1}\right)$ and the sewage flow $\left(\mathrm{m}^{3} \mathrm{~d}^{-1}\right)$.

- River velocity $(v)$, river depth $(H)$, and travel time $(t)$ : velocity and depth were inferred from the key curve at the selected fluviometric stations, using the cross section and the level series, both obtained from Hidroweb. The travel time was obtained by the ratio between the length of the river section and the velocity.

- DO saturation concentration (Cs): obtained as a function of river water temperature, ranging from $0^{\circ} \mathrm{C}=14.6 \mathrm{mg} \mathrm{L}^{-1}$ to $40^{\circ} \mathrm{C}=6.4 \mathrm{mg} \mathrm{L}^{-1}$ (Collischown and Tassi, 2010).

- Minimum permissible $D O\left(D O_{\min }\right)$ and maximum permissible BOD (BOD $\left.D_{\max }\right)$ : for $\mathrm{DO}_{\min }$ and $\mathrm{BOD}_{\max }$ in the river, the value of $5.0 \mathrm{mg} \mathrm{L}^{-1}$ was adopted, according to CONAMA Resolution $n^{\circ}$ 357/2005 (CONAMA, 2005) for Class 2.

- Coefficients of deoxygenation $\left(K_{1}\right)$, decomposition $\left(K_{d}\right)$. and reaeration $\left(K_{2}\right)$ : the $\mathrm{K}_{1}$ value depends on the temperature because it exerts considerable influence on microbial metabolism. The empirical relationship between temperature and the deoxygenation rate is given by Equation 3:

$K_{1_{T}}=K_{1_{20}} \times \theta^{(T-20)}$

Where: $K_{1}: \mathrm{K}_{1}$ at any temperature $\mathrm{T}\left(\mathrm{d}^{-1}\right) ; K_{1_{20}}: \mathrm{K}_{1}$ at temperature $\mathrm{T}=20^{\circ} \mathrm{C}\left(\mathrm{d}^{-1}\right)$; $\mathrm{T}$ : water temperature $\left({ }^{\circ} \mathrm{C}\right)$; and $\theta$ : temperature coefficient (dimensionless). The coefficients $\mathrm{K}_{\mathrm{d}}$ and $\mathrm{K}_{2}$ can also be defined by Equation 2 . For $\mathrm{K}_{1}$ and $\mathrm{K}_{\mathrm{d}}$, the value 1.047 is generally used for $\theta$, and for $\mathrm{K}_{2}, 1.024$. The coefficients $K_{1_{20}}, K_{d_{20}}$, and $K_{2_{20}}$ were extracted from Von Sperling (2007).

The calibration of the model was performed manually, varying the coefficients $\left(K_{1}, K_{d}\right.$, and $\mathrm{K}_{2}$ ) and obeying the value ranges (restrictions) found in the literature (Table 1), decreasing the sum of the squares of the errors until a satisfactory adjustment is obtained near 1 (Equation 4). This was based on the observed mean DO and BOD data from 2002 to 2010, taking the dry and rainy periods into consideration. The validation was done using the average values observed during the dry period between 2011 and 2014.

Table 1. Calibrated coefficients and reference values.

\begin{tabular}{llcccc}
\hline \multirow{2}{*}{ Coef. Description } & \multirow{2}{*}{ Unit } & Typical values* & \multicolumn{2}{c}{ Calibrated values** } \\
\cline { 4 - 6 } & & & & $1^{\text {st }}$ section & $2^{\text {nd }}$ section \\
\hline $\mathrm{K}_{1}$ & Deoxygenation coefficient & $\mathrm{d}^{-1}$ & 0.08 to 0.45 & 0.35 & 0.20 \\
$\mathrm{~K}_{\mathrm{d}}$ & BOD decomposition coefficient & $\mathrm{d}^{-1}$ & 0.10 to 3.00 & 1.72 & 0.60 \\
$\mathrm{~K}_{2}$ & Reaeration coefficient & $\mathrm{d}^{-1}$ & 0.00 to 10.00 & 7.00 & 6.00 \\
\hline
\end{tabular}

$*$ Von Sperling (2007). ** $1^{\text {st }}$ section: between UN-18 and UN-42; $2^{\text {nd }}$ section: between UN-42 and UN-45.

$R^{2}=1-\frac{\sum\left(Y_{O b s}-Y_{E s t}\right)^{2}}{\sum\left(Y_{O b s}-Y_{A v g O b s}\right)^{2}}$ 
Where: $\mathrm{R}^{2}$ : Nash-Sutcliffe coefficient; and $\mathrm{Y}_{\mathrm{Obs}}, \mathrm{Y}_{\text {Est }}$ and $\mathrm{Y}_{\text {AvgObs: }}$ observed, estimated, and average observed values.

\subsection{Preliminary framework proposal}

Due to the limited availability of water quality data, the framework was proposed for the Una River only, disregarding its tributaries and reservoirs.

With the results obtained from the water quality analysis and modeling, it was possible to establish a preliminary framework proposal for the main river channel related to the guidelines established in the current legislation, the uses identified in the basin, the water quality analysis data, and the simulation model of the Una River's behavior.

\section{RESULTS AND DISCUSSION}

\subsection{Analysis of water quality parameters}

The results of the analysis of the eight water quality parameters monitored at the six basin stations during the dry and rainy periods from 2002 to 2010 are discussed below and presented in Figure 2:

- Temperature: along the Una River, the water temperature ranged from $24^{\circ} \mathrm{C}$ to $33^{\circ} \mathrm{C}$, maintaining an average temperature of $28.1^{\circ} \mathrm{C}$. It is worth noting that CONAMA Resolution $n^{\circ} 357 / 2005$ (CONAMA, 2005) does not specify any temperature limits for the framework classes, but, for Amorim et al. (2017), high temperatures do decrease the solubility of gases, reducing the DO concentration.

- Potential Hydrogen $(p H)$ : despite the presence of industrial areas in the basin's municipalities, the $\mathrm{pH}$ values remained unchanged. The mean values found ranged from 6.0 to 9.0 at all monitoring stations, falling within the limit allowed by CONAMA Resolution $\mathrm{n}^{\mathrm{o}} 357 / 2005$ (CONAMA, 2005). Although its values were still found to conform to limits, it was observed that the $\mathrm{pH}$ at station $\mathrm{UN}-18$ varied little due to the low flow of the river along this section. Other UN-25, UN-30 and UN-42 stations presented lower mean $\mathrm{pH}$ values in the rainy season (UN-25: 7.00, UN-30: 6.30, UN42: 6.70) when compared to the dry period (UN-25: 7.10; UN-30: 6.85; UN-42: 6.95), corroborating with the results obtained by Piratoba et al. (2017). According to the author, this situation can be attributed both to natural factors (with increasing rainfall, the $\mathrm{pH}$ tends to rise, since dilution of dissolved compounds increases and there is a greater flow) for anthropogenic factors (through the launch of domestic and industrial sewage affecting the $\mathrm{pH})$.

- Dissolved Oxygen (DO): the highest variation in DO was found to be concentrated at stations UN-30 (dry season) and UN-25 (rainy season) with intervals of 0 to $6.80 \mathrm{mg} \mathrm{L}^{-1}$ and 1.80 to $9.10 \mathrm{mg} \mathrm{L}^{-1}$, respectively. These large fluctuations in DO concentration in Una River waters were also observed by Melo et al. (2018), identifying variations from 0.9 to $9.5 \mathrm{mg} \mathrm{L}^{-1}$. Because of these large fluctuations, the monitored DO values (for all seasons) were at some point outside of the limit recommended in CONAMA Resolution $n^{\circ} 357 / 2005$ (CONAMA, 2005) for Class 2, which is $\geq$ $5 \mathrm{mg} \mathrm{L}^{-1}$. This fact can be associated with the intense urban occupation along the banks of the river, which releases effluent from domestic sources, industry, and public slaughterhouses directly into the river. Another contributing factor is related to the presence of the Pumaty Plant, located upstream of the UN-42 station, which greatly influences water quality, especially during the dry season. Nevertheless, at stations UN$18, \mathrm{UN}-25, \mathrm{UN}-42$ and UN-45, the mean DO values were within the limit specified in the resolution across the entire study period. 
- Biochemical Oxygen Demand (BOD): at stations UN-18, UN-25 and UN-30, the BOD parameter was observed to be higher than the limit established by the current environmental legislation (Class $2 \leq 5 \mathrm{mg} \mathrm{L}^{-1} \mathrm{O}_{2}$ ) at sometimes. For example, during the dry season, a maximum of $25 \mathrm{mg} \mathrm{L}^{-1}$ was recorded, while during the rainy season, BOD values above $20 \mathrm{mg} \mathrm{L}^{-1}$ were found. The increase in the BOD values indicates an increase in the concentration of organic matter in the river, suggesting the increase of the potential for pollution. On the other hand, when the analysis is done using average values, they were found to be in compliance with the limit established for Class 2 . According to Cetesb (2006), waters with BOD of less than $4 \mathrm{mg} \mathrm{L}^{-1}$ are classified as clean waters, and waters with BOD values above $10 \mathrm{mg} \mathrm{L}^{-1}$, as polluted. From this criterion, also used by Amorim et al. (2017), and considering only the mean values monitored for BOD at all stations, the Una river waters were considered clean during the analyzed period.

- Color: federal environmental legislation indicates the natural true color level for a water body has a maximum limit of $75 \mathrm{mg} \mathrm{L}^{-1} \mathrm{Pt}$ for fresh water. After analyzing the data, it was found that during the dry period, only the UN-30 station had maximum values above the recommended limit. During the rainy season, the recommended maximum level was exceeded by stations UN-30, UN-42, and UN-45. In average terms, this parameter presented values that were within the limit established by legislation.

- Turbidity: the average turbidity levels were within the maximum limit established by CONAMA Resolution $n^{\circ}$ 357/2005 (CONAMA, 2005), $\leq 100$ UNT, considering both dry and rainy seasons. During the dry season, only station UN-18 presented values above that foreseen by legislation, with peaks of 250 UNT. It was found that the greatest variations in turbidity are related to the presence of suspended materials during the rainy season. It was verified that the higher variations of this parameter are related to the presence of suspended materials during the rainy season, since the surface runoff has a direct relation of influence with the turbidity, according to Costa Filho et al. (2017). In addition, domestic sewage and various industrial effluents can also cause water turbidities to rise.

- Phosphorus: the phosphorus concentrations ranged from 0.01 to $0.81 \mathrm{mg} \mathrm{L}^{-1}$ in the rainy season and from 0.02 to $1.48 \mathrm{mg} \mathrm{L}^{-1}$ in the dry season. At all monitoring stations, these values are above the limit established by CONAMA Resolution $n^{\circ}$ 357/2005 (CONAMA, 2005), when evaluated for Classes 1 and 2. This situation was also observed by Melo et al. (2018) when the water quality was evaluated in regions close to the four reservoirs (currently under construction) located in the perennial stretch of the Una river, from March/2014 to April/2015. These results demonstrate the high level of contribution of nutrients resulting from the fertirrigation practices of sugarcane, and from effluent release by municipalities, which may cause problems such as eutrophication and toxic algal blooms.

- Thermotolerant coliforms: the maximum values observed during the dry and rainy seasons are on the order of 10,000 NMP $100 \mathrm{ml}^{-1}$, while the average values are above 1,000 NMP $100 \mathrm{ml}^{-1}$ (limit established for Class 2). Only UN-27 presented, on average, values in accordance with the current environmental legislation, when both dry and rainy seasons were analyzed. This is because there is funding from COMPESA (Pernambuco Sanitation Company) that guarantees periodic monitoring to meet water quality standards in this area. The high levels of thermotolerant coliforms point towards fecal contamination from domestic effluents, released by the municipalities of Água Preta, Palmares and Barreiros. 
DRY SEASON

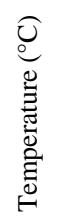

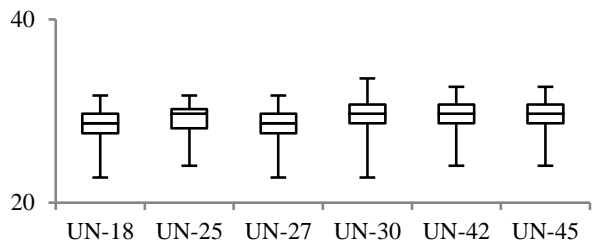

.

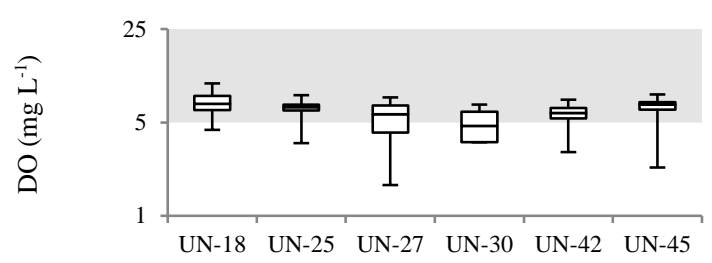

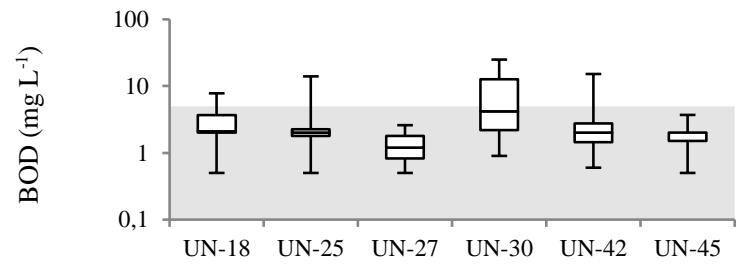

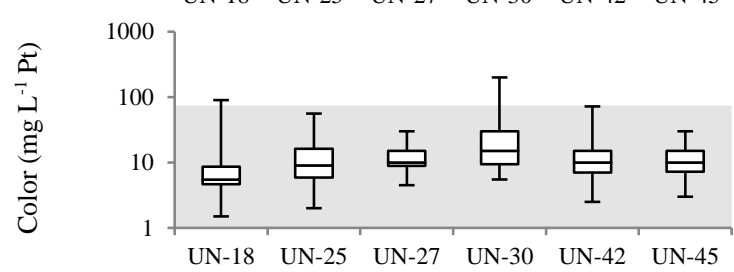

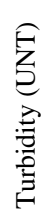

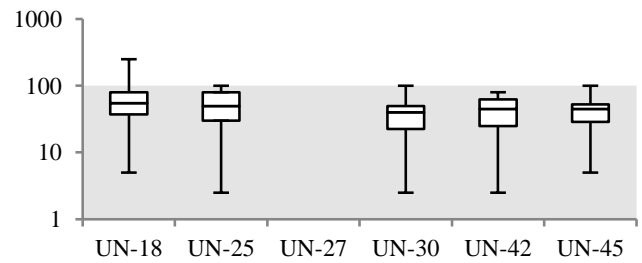

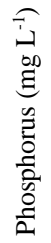

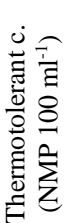
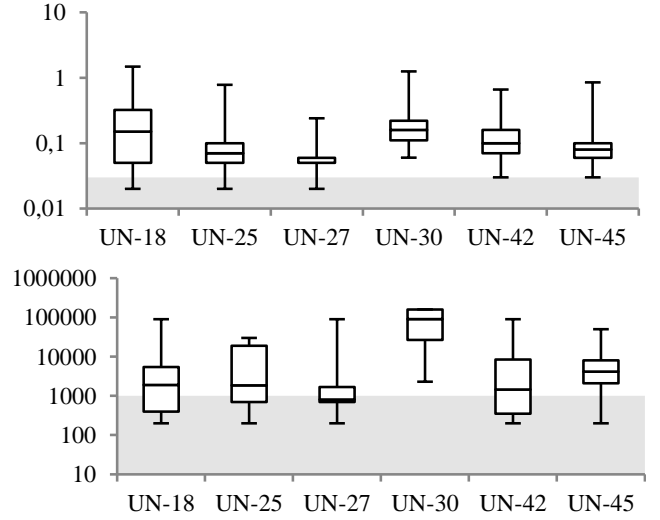

RAINY SEASON
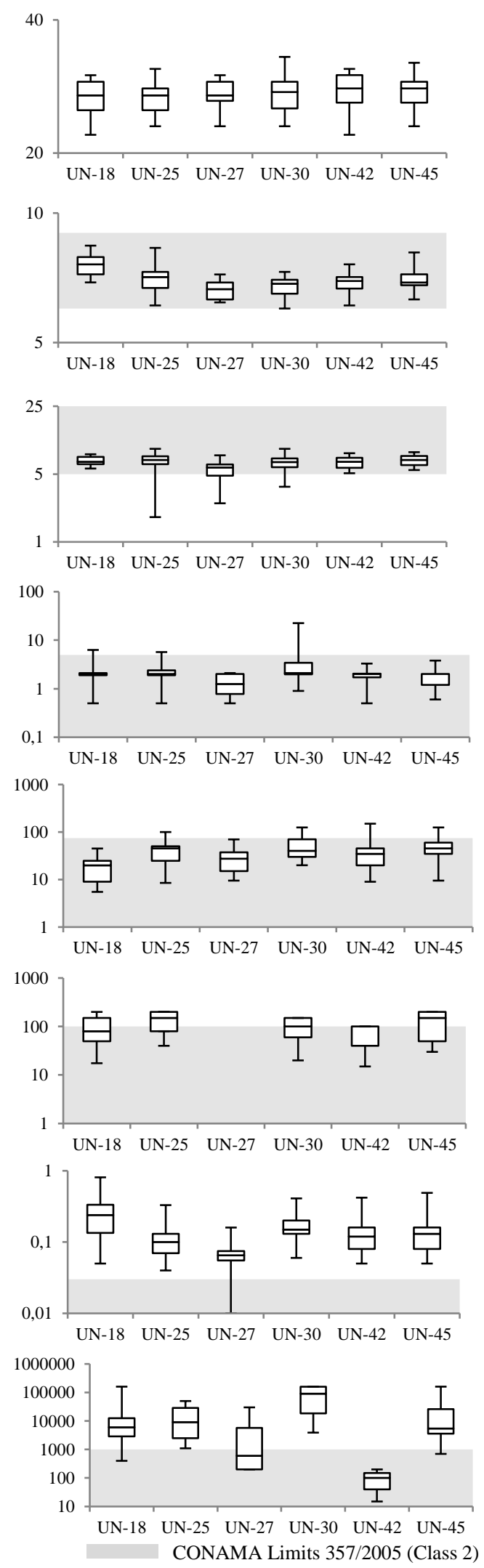

Figure 2. Graphical analysis of water quality parameters. 


\subsection{Simulation of DO and BOD parameters on a perennial section of the Una River}

The manual calibration of the QUAL-UFMG model resulted in a satisfactory adjustment between the estimated and observed DO and BOD values. The Nash-Sutcliffe coefficients $\left(\mathrm{R}^{2}\right)$ for both parameters were calculated at 0.998 and 0.999 , respectively. This means that the model was able to represent $99.8 \%$ and $99.9 \%$ of the variance in the experimental DO and BOD data. During the validation of the model, performed only for the dry season between the years 2011 and 2014, it was observed that the simulated parameters (DO and BOD) were representative when compared to the observed data $\left(R_{D O}^{2}=0.709\right.$ and $\left.R_{B O D}^{2}=0.779\right)$.

The results of the simulation showed that the Una River has a high dilution capacity, since the modeled section, even in the dry season, had a high flow rate. It was also observed that, during the period from 2002 to 2010, the simulations of both DO and BOD along the section modeled were within the CONAMA Resolution $n^{\circ} 357 / 2005$ (CONAMA, 2005) Class 2, 100\% and $99.5 \%$, respectively (Figure 3a). In the period from 2011 to 2014, the simulated DO and BOD parameters met the limits of the above-mentioned resolution for Class 2 for $100 \%$ of the modeled section (Figure 3b). This result does not invalidate the need to install sanitary sewage systems for the municipalities within the basin (with an efficiency greater than $90 \%$ ), since they do not have adequate systems to treat effluents and as population grows, increased organic load could lead to public health problems. Figure 3 shows the simulation of the DO and BOD parameters, based on the calibration and validation of the model.
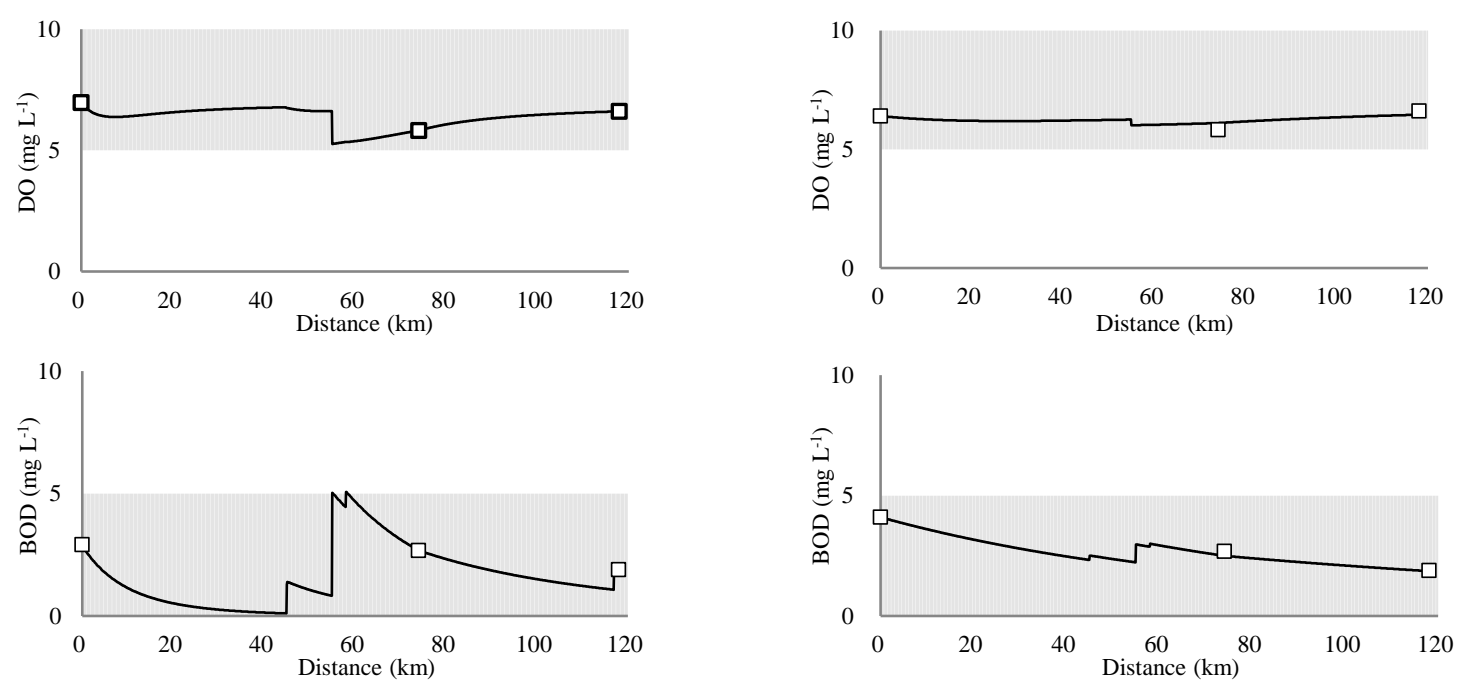

(a)

(b)

CONAMA 357/2005 Limits (Class 2) Observed values Estimated values

Figure 3. (a) Calibration of the DO and BOD parameters for the period from 2002 to 2010. (b) Validation of the DO and BOD parameters for the dry season from 2011 to 2014.

\subsection{Presentation of the preliminary framework proposal}

Based on the results obtained from the water quality analysis, mathematical modeling, and knowledge of current water use in the basin, Figure 4 represents the proposal established for the Una River framework. In this preliminary proposal, the proposed framework classes and the multiple predominant water use along four stretches of the river are identified, namely: 


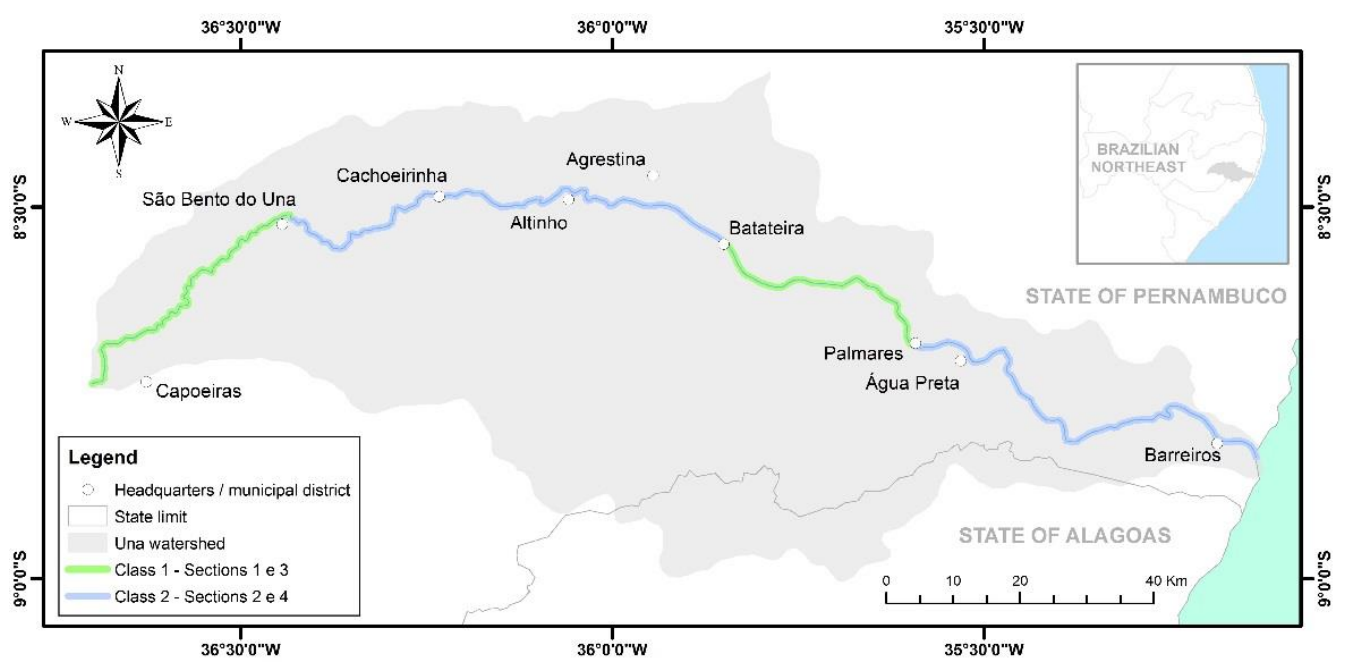

Figure 4. Identification of the sections framed by intended use class.

- Section 1 (Source until São Bento do Una): most of this section passes through rural areas, without the presence of industry or activities of great size. Thus, when water is present along this stretch, the local population will draw it from the river for human consumption, in addition to using it for domestic activities such as washing clothes, and recreation. Therefore, the current practices justify the proposed Class 1 framework. On the other hand, this section is also characterized by diffuse pollution, which compromises water quality to a lesser extent (presenting parameters consistent with Class 2), because it is intermittent during most of the year. The predominant uses are: human and animal water supply; irrigation of fruits and vegetables consumed raw that grow along the ground; and recreation.

- Section 2 (São Bento do Una until the vicinity of Batateiras): the analysis of the monitored water quality data suggested that this section be classified as Class 2, establishing the prevailing uses already being practiced along this section. A large volume of untreated domestic effluent from the municipalities upstream of the district of Batateiras was identified throughout this section. The prevailing uses are: human, animal and industrial water supply; and irrigation of sugarcane crops.

- Section 3 (Vicinity of Batateiras until Palmares): in this section, the Una River receives flow from other tributaries, which improves its capacity to self-purify the organic matter, even during the dry season, as shown by the results of the OD and BOD parameter modeling. Although such parameters are within the limits of Class 2, this section was classified as Class 1, demanding more severe standards of water quality, since the greater use of water in this section is destined to agriculture. In this case, the preponderant intended uses are: human and animal water supply; and irrigation of fruits and vegetables consumed raw that grow along the ground.

- Section 4 (Palmares until the mouth of the Una River): very little water is captured from this section for human supply, but a large amount is used for agriculture. Many municipalities in this region have small plots with sanitary sewage coverage, favoring a large load of domestic and industrial effluent (such as the Pumaty Plant operation), which are released directly into the river. Despite this, decreases in the BOD levels occur due to the increased flow from tributaries in this stretch, in addition to the significant increase in rainfall, resulting in a considerable capacity for self-purification. This situation, together with the water quality analysis and modeling, justifies the proposed Class 2 framework for this section. The predominant uses are: human, animal and industrial water supply; and irrigation of sugarcane. 


\section{CONCLUSIONS}

The water quality analyses showed that, in average terms, most of the parameters monitored during the dry and rainy seasons are within the limits established by CONAMA Resolution $n^{\circ} 357 / 2005$ (CONAMA, 2005), for Class 2. Only the parameters of phosphorus and thermotolerant coliforms are outside the standards recommended by the aforementioned legislation, a fact mainly associated with the release of domestic, industrial, and public slaughterhouse effluents from urban areas along the river shore.

In spite of this, the water quality modeling showed that the Una River has a high selfpurification capacity along its perennial stretch, even during the dry season, considered to be the most critical. This result is justified by the fact that the Una River basin is located in an area with high rainfall, characteristic of the southern part of the State of Pernambuco.

This hydraulic and hydrological condition of the basin made it possible to classify some stretches of the Una River as Class 1, establishing prevailing uses with more strict water quality standards, even when somewhat distant from the current practices. To this end, a framework implementation program should be established, whereby the intermediate progressive goals of water quality improvement can be defined. In the case of the Una River, it is extremely necessary to control the sources of water pollution, through adaptation to the release standards for industrial effluents and the implementation of sewage systems for the municipalities along the river.

With this proposal, the Una River will have a set of monitoring parameters that will serve as a reference for achieving and maintaining the required water quality, in order to ensure water quality compatible with its intended uses.

\section{REFERENCES}

AGÊNCIA ESTADUAL DE MEIO AMBIENTE E RECURSOS HÍDRICOS - CPRH (PE). Resultados do monitoramento das bacias. Available at: http://www.cprh.pe.gov.br. Access on: 17 Feb. 2018.

AMORIM, D. G.; CAVAlCANTE, P. R. S.; SOARES, L. S.; AMORIM, P. E. C. Enquadramento e avaliação do índice de qualidade da água dos igarapés Rabo de Porco e Precuá, localizados na área da Refinaria Premium I, município de Bacabeira (MA). Engenharia Sanitária e Ambiental, v. 22, n. 2, p. 251-259, 2017. http://dx.doi.org/10.1590/S1413-41522016131212

ARAUJO, A. F. Modelagem matemática da qualidade da água como suporte ao enquadramento de corpos de água: o caso do Rio Sirinhaém - PE. 2013. 94f. Dissertação (Mestrado em Tecnologia Ambiental) - Instituto de Tecnologia de Pernambuco, Recife, 2013.

BRASIL. Presidência da República. Casa Civil. Lei Federal nº 9.433, de 8 de janeiro de 1997. Institui a Política Nacional de Recursos Hídricos e cria o Sistema Nacional de Gerenciamento de Recursos Hídricos. Diário Oficial [da] União, Brasília, DF, 8 jan. 1997.

COLLISCHONN, W.; TASSI, R. Introduzindo a hidrologia. Porto Alegre: IPH/URGS, 2010. $151 \mathrm{p}$.

COMPANHIA AMBIENTAL DO ESTADO DE SÃO PAULO - CETESB. Qualidade das águas interiores no Estado de São Paulo. São Paulo, 2006. CETESB. Available in: https://cetesb.sp.gov.br/aguas-interiores/publicacoes-e-relatorios/. Access in: 04 jan. 2018 . 
CONSELHO NACIONAL DE RECURSOS HÍDRICOS (Brasil). Resolução nº 91, de 5 de novembro de 2008. Dispõe sobre procedimentos gerais para o enquadramento dos corpos de água superficiais e subterrâneos. Diário Oficial [da] União, Brasília, DF, 5 nov. 2008.

CONSELHO NACIONAL DO MEIO AMBIENTE (Brasil). Resolução n ${ }^{\circ}$ 357, de 17 de março de 2005. Dispõe sobre a classificação dos corpos de água e diretrizes ambientais para o seu enquadramento, bem como estabelece as condições e padrões de lançamento de efluentes, e dá outras providências. Diário Oficial [da] União, Brasília, DF, 17 mar. 2005 .

COSTA FILHO, E.; CRUZ, K. K. T.; GOMES, M. M. A. Estudo sobre a influência do escoamento superficial no parâmetro de turbidez na bacia hidrográfica do rio Pirapama, Pernambuco, Brasil. In: ENCONTRO INTERNACIONAL DAS ÁGUAS, 9., Recife, 2017. Trabalhos... Recife: Unicap, 2017.

FAN, C.; WANG, W.; LIU, K. F.; YANG, T. Sensitivity Analysis and Water Quality Modeling of a Tidal River Using a Modified Streeter-Phelps Equation with HEC-RAS-Calculated Hydraulic Characteristics. Environmental Modeling \& Assessment, v. 17, n. 1, p. 639651, 2012. https://doi.org/10.1007/s10666-012-9316-4

GOMES, F. C.; SIMÕES, S. J. C. Simulação de modelagem qualitativa para avaliação preliminar da qualidade da água na bacia do Ribeirão das Perdizes em Campos do Jordão/SP, como subsídio ao enquadramento. Revista Brasileira de Recursos Hídricos, v. 19, n. 3, p. 309-326, 2014.

LIMA, E. E. S. Modelagem matemática da qualidade da água como suporte ao enquadramento da bacia do rio Una - PE. 2016. 108f. Dissertação (Mestrado em Tecnologia Ambiental) - Instituto de Tecnologia de Pernambuco, Recife, 2016.

LOUZADA VALORY, J. P.; REIS, J. A. T.; MENDONÇA, A. S. F. Combining genetic algorithms with a water quality model to determine efficiencies of sewage treatment systems in watersheds. Journal of Environmental Engineering, v. 142, p. 04015080, 2016. https://doi.org/10.1061/(ASCE)EE.1943-7870.0001048

MELO, D. F. B. C.; RIBEIRO, M. H. G.; ALBUQUERQUE JUNIOR, E. C.; GONÇALVES, E. A. P. Avaliação da bacia do rio Una-Pernambuco: perspectiva da qualidade da água após a construção de 4 barragens para contenção de cheias. Revista Brasileira de $\begin{array}{lllllll}\text { Geografia } & \text { Física, } & \text { v. } 11, \quad \text { n. } & 2, & \text { p. }\end{array}$ https://doi.org/10.26848/rbgf.v11.2.p612-627

PERNAMBUCO. Lei Estadual n ${ }^{\circ}$ 12.984, de 30 de dezembro de 2005. Dispõe sobre a Política Estadual de Recursos Hídricos e o Sistema Integrado de Gerenciamento de Recursos Hídricos, e dá outras providências. Diário Oficial [do] Estado de Pernambuco, Recife 30 dez. 2005.

PINHEIRO, R. B.; MONTENEGRO, S. M. G. L.; SILVA, S. R.; MEDEIROS, Y. D. P.; AURELIANO, J. T. Outorga para Lançamento de Efluentes - Uma Metodologia de Apoio à Gestão de Recursos Hídricos. Revista Brasileira de Recursos Hídricos, v. 18, n. 4, p. 55-65, 2013.

PIRATOBA, A. R. A.; RIBEIRO, H. M. C.; MORALES, G. P.; GONÇALVES E GONÇALVES, W. Caracterização de parâmetros de qualidade da água na área portuária de Barcarena, PA, Brasil. Revista Ambiente \& Água, v. 12, n. 3, p. 435-456, 2017. https://doi.org/10.4136/ambi-agua.1910 
SILVA, M. C. A. A. Modelagem matemática da qualidade da água como suporte ao enquadramento da bacia do rio Goiana - PE. 2015. 109f. Dissertação (Mestrado em Tecnologia Ambiental) - Instituto de Tecnologia de Pernambuco, Recife, 2015.

SILVA, M. A. P. M.; FARIA, S. D.; MOURA, P. M. Modelagem da qualidade da água na bacia hidrográfica do Rio Piracicaba (MG). Engenharia Sanitária e Ambiental, v. 22, n. 1, p. 133-143, 2017.

VON SPERLING, M. Estudos e modelagem da qualidade da água de rios. Belo Horizonte: DESA/UFMG, 2007. 588 p. 